\title{
ADDITIONS TO THE LIST OF KANSAS DIPTERA.
}

By F. F. Creveccur, Onaga, Kan.

THE following list of Diptera which have not before been listed from the state were all collected by me near my home near Onaga. A number of uniques, and a few undetermined species which are probably undescribed, are not included in this list, but will be reserved until some future time, when I expect to list them along with a lot of Microdiptera which so far I have not taken the trouble to collect. From the number of new species taken the last year or two, and the limited territory over which collecting in this order has been done, it is evident there is much yet to be done in the way of cataloguing the Diptera of the state; so that this list, as well as that of Doctor Snow, published in the Kansas University Science Bulletin, volume II, No. 5, November, 1903, may be considered only a preliminary one.

\section{Family TIPULIDÆ.}

Dicranoptycha sobrina $\mathrm{O}$. S.

Common on weeds in the timber the latter part of May.

Erioptera graphica O. S.

Common on weeds in the timber, and also along sloughs, through the month of May. I took several specimens in the house last November and December.

Gnophomyia tristissima O. S.

Common in sweepings from weeds in heavy timber in May.

Pachyrhina punctum Loew.

A common fly on the prairie, especially on the hills and rougher ground during early summer.

Tipula angustipennis Loew.

Common; taken in the timber and in an orchard on the upland the latter part of April.

Tipula trivittata Say.

Among weeds and bushes along creeks the latter part of August.

Family CHIRonomidæ.

Ceratopogon variipennis Coq.

This little chironomid is occasionally taken while milking the cows towards evening, when it may be seen forcing its way among the cows' hair to satisfy its thirst for blood. The one specimen in my collection was taken May 29, 1905.

Family MycetophiLID 2.

Mycetophila punctata Meig.

The only specimen I have of this species was found under a board lying on the ground in the dooryard March 27, 1903. 


\section{Family SimuliIdæ.}

Simulium venustum Say.

One specimen, taken May 22, 1901.

Simulium vittatum Zett.

This little pest is often abundant the latter part of March and early in April, hovering about and entering horses' and cattle's ears, where it gorges itself on the animals' blood. Last year I found the species quite common as late as November 23.

\section{Family Stratiomyid}

Odontomyia (snowi) hieroglyphica Olivier.

Common from early summer until fall, frequenting the flowers of Compositæ.

Pachygaster maculicornis Hine.

I have no specimens of this species in my collection, but in Aldrich's catalogue of North American Diptera this species is credited to Onaga, Kan.; so I suppose a specimen was included among a lot of flies sent by me to Professor Hine.

Tabanus bicolor Wied.

\section{Family TABANIDÆ.}

A few specimens of this fly were taken on swampy ground during June. The male was taken frequenting the flowers of Cicuta maculata July 16, 1903.

Tabanus costalis Wied.

This tabanid is common during the hot summer months, attacking cattle and horses.

Tabanus dodgei Whitney.

This fairly common species I have taken only while plowing or listing, when it would be seen flying about the working horses. Occurs only in May.

Tabanus lineola Fabr.

A number of Tabanus which I thought were longus, sent to Professor Hine, of the State University of Ohio, last fall, were mentioned by him in a communication to me as T. lineola.

Tabanus (Tectus) sulcifrons Macq.

This large fly abounds near wooded streams during June and July, where it makes life unendurable to live stock confined in lots near the creeks.

\section{Family LEPTID}

Cœnomyia furruginea Scopoli.

Some years this fly is quite abundant among the rank growth of weeds in the timber along the creeks during the first part of June.

Xylomyia (Subula) parens Wills.

A specimen was taken in the timber on French creek June 7, another in our orchard on the prairie June 13, and a third specimen was taken in our house May 28.

Chrysopila testaceipes Bigot.

Quite common on the rank herbage in the heavy timber along the larger streams during the month of June. 


\section{Family BомвYLIIDA.}

Spogostylum œdipus Fabr.

Common about flowers on the prairie during July and August.

Anthrax ceyx Loew.

The only time I have met with this species was on August 16, 1897, when I took a half a dozen or so on the blossoms of a species of Solidago at the edge of the timber along French creek, four miles north of Onaga.

Anthrax sinuosa Wied.

I have taken this on the prairie and in the timber; it occurs from June until August.

Bombylius major Linne.

I have taken this species on blossoms of the apricot from April 13 to April 17.

Leptogaster varipes Loew.

Family AsILID

Some years quite common; on the prairies during the latter part of June.

Ospriocerus eutrophus Loew.

This rare and pretty species I have taken in rank grass on the prairie in July.

Ecthodopa pubera Loew.

Occurs from the last of May to the last of August along the larger streams among the weeds in the timber.

Holcocephala abdominalis Say.

Abundant along sloughs, where it frequents flowers growing in such situations. June to July.

Atomosia puella Wied.

Common. I have taken it along sloughs and in the timber along the creeks from June to September.

Ommatius marginellus Fabr.

The two specimens I have of this rare species were taken the first week in July, one in the timber and the other on the prairie.

Erax rapax O. S.

A rather uncommon species; taken on the prairie in September. I have a pair taken in copula, and find the sexes differ considerably.

Tolmerus annulipes Macq.

What has been determined as this species was taken in heavy timber early in July.

\section{Family DoLICHOPODIDÆ.}

Psilopodinus sipho Say.

Abundant in the timber, where it may be seen disporting itself in the sunlight upon the tops of the weeds. Occurs from the last of May till the last of June.

Diaphorus leucostomus Loew.

One of my notes says: Apparently lapping dew on the leaves of boxelder, May 23. Also taken in sweepings on the grass and weeds in the pasture on the prairie June 24 .

Dolichopus scoparius Loew.

I have but one specimen of this species in my collection, which was taken in heavy timber May 17, 1898. 
Hybos triplex Walk.

Taken in sweepings on the prairie May 26, 1897.

Hilara femorata Loew.

The one specimen I have of this species was taken May 12, 1901. My notes do not say in what situation, but I think I recollect taking it on the window of our residence.

Rhamphomyia fumosa Loew.

Common on the weeds in the timber during May and June.

Microdon fuscipennis Macq.

Family Syrphid E.

A single specimen taken about fifteen years ago is all that I have ever seen of this species. The specimen has no date or other labels, as I put no labels on my specimens then.

Mixogaster breviventris Kahl.

A number of uniques given to Professor $\mathrm{Kahl}$ while he was yet at the Kansas State University contained a specimen which he determined as this species, but as he retained the specimen, with its accompanying note, I cannot tell when or in what situation it was taken.

Chrysotoxum derivatum Walk.

An uncommon species. Have taken it frequenting flowers along a slough the last week in June; also in heavy timber the last week in August.

Baccha fascipennis Wied.

A few taken in heavy timber the middle of June.

Mallota posticata Fabr.

I have met with this species but once; a half-dozen or so were sunning themselves on the tops of Impatiens pallida on French creek June 12, 1904.

Xylota chalybea Wied.

One of my uniques determined by Professor Kahl. I have a fly taken since, which from memory I think is this species, which was taken May 12, 1901.

\section{Family TachINIDÆ.}

Leskia analis Say.

Taken on weeds in the timber the latter part of July.

Leucostoma senilis Town.

On weeds and bushes in the timber the last week in June, and on the blossoms of Solidago in the pasture the middle of September.

Estrophasia ochracea Bigot.

Taken on the prairie in September and October. I once found a specimen in water put in a sorghum evaporator over night.

Estrophasia signifera Van der Wilp.

Taken the last of May.

Ocyptera carolina Desv.

Taken in beating net on the prairie the latter part of June, and on blossoms of Solidago, also on the prairie, early in September.

Acemyia tibialis Coq.

Taken on the prairie June 22, and at light September 22. 
Archytas aterrima Desv.

A common species. The only specimens in my collection are among some of my earliest captures in entomology and bear no date or other labels.

Sarcophaga sarraceniæ Riley.

Like the preceding species, my specimens of this bear no date or other labels. A common species.

Cynomia cadaverina Desv.

My remarks on the two preceding species also apply to this.

Myiospila meditabunda Fabr.

Rare. Taken under a piece of cloth placed in the crotch of a tree in the dooryard, to serve as a trap for insects, April 20, 1897.

Ophyra leucostoma Wied.

Taken on Salix longifolia April 25; also taken while maintaining itself in a stationary position on the wing, in the orchard, August 18.

Phorbia acra Walk.

Taken in the orchard April 23; also at the edge of heavy timber along the creek June 16.

Phorbia cinerella Fall.

This little pest, to which I have applied the rather opprobrious epithet of " snot fly," on account of its persistency in trying to fly to one's nose when one is affected with catarrh, is quite common all summer from April on. I once reared a specimen from a pupa found in the shriveled skin of a Geophilus perforans under a stone on the prairie.

Caricea antica Walk.

Found among sweepings made in the orchard April 24; also collected in sweepings made on the prairie May 12.

\section{Family SCATOPHAGID}

Cordylura gracilipes Loew.

Taken in sweepings in heavy timber in May.

Scatophaga furcata Say.

Common in the timber in July.

Sciomyza nana Fall.

Family ScIOMYZID $\approx$.

Beaten from Ambrosia artemisiæfolia October 23, 1897.

Tetanocera arcuata Loew.

A common species; taken in the orchard in April, and in heavy timber in June.

Tetanocera plumosa Loew.

Taken on vegetation growing on swampy ground the middle of June.

Tetanocera saratogensis Fitch.

Common in pastures in May.

Tetanocera umbrarum Linné.

Taken on weeds in a pasture in October.

\section{Family SAPROMYZID}

Lonchæa rufitarsus Macq.

This species frequents carrion, and my specimens were taken the middle of April. 
Palloptera superba Loew.

A rare species. One of the two specimens I have was taken in the timber on a small creek July 7, and the other in the heavy timber on a larger stream July 5 .

Sapromyza crevecœuri Coq.

Taken on hazel bushes from the last of June till early in August.

Sapromyza lupulina Fabr.

Taken on weeds in the timber from the last of May till the middle of June.

Sapromyza philadelphica Macq.

Taken on prairie, and on weeds at the edge of timber, during the latter half of June.

Sapromyza vulgaris Fitch.

Swept on the prairie May 30.

Pyrgota valida Harris.

Family ORTALIDA.

I have taken this species a number of times in my cloth traps in the trees in the dooryard the latter part of April.

Amphicnephes fasciola Coq.

The types of this species were collected by myself. It is a common species, and is found by beating the vegetation growing in pastures from June until September.

Tritoxa incurva Loew.

One of the uniques determined by Professor Kahl, and my remarks on Mixogaster breviventris (supra) also apply to this species.

Pterocalla strigula Loew.

A rare species, and the only specimen I have was taken by sweeping in heavy timber May 18, 1898.

Euxesta notata Wied.

Taken on carrion April 24, and in sweepings in heavy timber May 18.

Family Trypetid

Straussia longipennis Wied.

This species has been listed by Doctor Snow. I have specimens which Professor Hine determines as this species but which I think is a different species, as it is quite different from the form usually known by this name. The wings of my species are narrower than common S. longipennis, and the markings in the wings form a dark band occupying about two-thirds of the costal border of the wing. I feel satisfied that when the species comes to be more thoroughly studied it will be found to be distinct from longipennis.

Eutreta rotundipennis Loew.

On weeds in heavy timber the middle of June.

Eurosta comma Wied.

Taken in fair numbers in a pasture early in October.

Eurosta reticulata Snow.

A rather scarce species. Taken on the prairie May 25, 1900. 
Calobata lasciva Fabr.

Family Micropezid $A$.

This common species may be taken in the timber early in June while it disports in the sunlight on the tops of the weeds.

Family SEPSID $\approx$. .

Prochyliza xanthostoma Walk.

I have taken this species in my sweepings in the orchard from the latter part of April to early in May.

Psila lateralis Loew.

\section{Family PsILID}

Occurs on vegetation along sloughs and in the timber during the first half of June.

Ochthera mantis DeG.

$$
\text { Family EPHYDRIDÆ. }
$$

Common on the wet ground at the edge of a stock pond on my place in June. One specimen I have was swept from the vegetation growing along a slough June 4.

Chlorops proxima Say.

Family Oscinid

Swept in a low meadow the latter part of May; also taken on blossoms of Solidago in the pasture September 11.

Hippelates plebejus Loew.

I have taken this species the latter part of June while milking, while it was crawling over the cows, being presumably attracted by the smell of fresh milk.

\section{Family DrosophiLID}

Phortica vittata Coq.

One specimen I have was taken May 12, 1901.

Family AGRomyzid

Agromyza neptis Loew.

Taken while evidently feeding on the dew on box-elder leaves in the orchard in May, and swept on the prairie June 22. 


\section{$2 \mathrm{BHL}$ Biodiversity Heritage Library}

Crevecoeur, F. F. 1906. "Additions to the list of Kansas Diptera." Transactions of the Kansas Academy of Science 20, 90-96. https://doi.org/10.2307/3624689.

View This Item Online: $\underline{\text { https://www.biodiversitylibrary.org/item/35329 }}$

DOI: https://doi.org/10.2307/3624689

Permalink: $\underline{\text { https://www.biodiversitylibrary.org/partpdf/2888 }}$

\section{Holding Institution}

Harvard University, Museum of Comparative Zoology, Ernst Mayr Library

\section{Sponsored by}

Harvard University, Museum of Comparative Zoology, Ernst Mayr Library

\section{Copyright \& Reuse}

Copyright Status: NOT_IN_COPYRIGHT

This document was created from content at the Biodiversity Heritage Library, the world's largest open access digital library for biodiversity literature and archives. Visit BHL at https://www.biodiversitylibrary.org. 